\title{
The effect of dexmedetomidine on gastric ischemia reperfusion injury in rats. Biochemical and histopathological evaluation
}

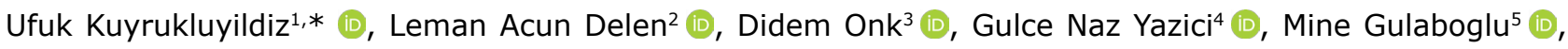 \\ Halis Suleyman ${ }^{6}$
}
1.Associate Professor. Erzincan Binali Yıldırım University - Faculty of Medicine - Department of Anesthesiology and Reanimation - Erzincan, Turkey.
2.PhD. Malatya Research and Training Hospital - Department of Anesthesiology and Reanimation - Malatya,Turkey.
3.Associate Professor. Erzincan Binali Yıldırım University - Faculty of Medicine - Department of Anesthesiology and Reanimation - Erzincan, Turkey.
4. Assistant Professor. Erzincan Binali Yıldırım University - Faculty of Medicine - Department of Histology and Embryology
- Erzincan, Turkey.
5.Professor. Ataturk University - Faculty of Pharmacy - Department of Biochemistry - Erzurum, Turkey.
6.Professor. Erzincan Binali Yıldırım University - Faculty of Medicine - Department of Pharmacology - Erzincan, Turkey.

\begin{abstract}
Purpose: To evaluate the protective effect of dexmedetomidine on gastric injury induced by ischemia reperfusion (I/R) in rats. Methods: A total of 18 male albino Wistar rats were divided groups as: gastric ischemia reperfusion (GIR), gastric ischemia reperfusion and $50 \mu \mathrm{g} / \mathrm{kg}$ dexmedetomidine (DGIR) and sham operation (HG) group. After the third hour of reperfusion, the biochemical and histopathological examinations were performed on the removed stomach tissue. Results: Malondialdehyde (MDA) and myeloperoxidase (MPO) levels were found to be significantly higher in GIR compared to HG $(p<0.05)$. A statistically significant decrease was observed at the DGIR compared to the GIR for oxidants levels. Total glutathione (tGSH) and superoxide dismutase (SOD) levels were statistically significantly decreased at the GIR, and antioxidants levels were found to be significantly higher in the DGIR $(p<0.05)$ There was no significant difference between HG and DGIR in terms of SOD ( $p=0.097)$. The DGIRs' epitheliums, glands and vascular structures were close to normal histological formation. Conclusions: Dexmedetomidine is found to prevent oxidative damage on the stomach by increasing the antioxidant effect. These results indicate that dexmedetomidine may be useful in the treatment of ischemia-reperfusion-related gastric damage.
\end{abstract}

Key words: Reperfusion Injury. Oxidative Stress. Dexmedetomidine. Stomach. Rats.

*Corresponding author: drufuk2001@gmail.com | (+90) 4462261818

Received: Sept 12, 2020 || Review: Nov 09, 2020 | Accepted: Dec 11, 2020

Conflict of interest: Nothing to declare.

Research performed at Ataturk University Medical Experimental Application and Research Center (ATADEM), Ataturk University, Erzurum, Turkey. 


\section{Introduction}

The stomach damage caused by ischemia reperfusion $(\mathrm{I} / \mathrm{R})$ is an important clinical problem associated with various physiopathological events ${ }^{1}$. It is known that many hemorrhagic conditions including peptic ulcer bleeding, hemorrhagic shock, vascular rupture, and surgery may lead to gastric $I / R^{2}$. The ischemic damage is defined as the pathological changes that occur due to the deprivation of oxygen in tissues or organs as a result of a decrease or complete interruption of the blood flow to the tissues, for various reasons ${ }^{3}$. Reperfusion is the restoration of the blood flow to the ischemic tissues ${ }^{4}$. If the blood flow to the ischemic tissue is not restored, a series of pathological events, which may progress to cellular dysfunction and cell necrosis, develop ${ }^{5}$. However, paradoxically,it has been reported that rapid reperfusion of ischemic tissue can cause much more severe damage compared to the damage caused by ischemia alone ${ }^{4}$. The reperfusion injury is caused by overproduction of reactive oxygen radicals (ROS), known as reperfusion mediators, by molecular oxygen, which are presented to ischemic tissue in large quantities by arterial blood ${ }^{6,7}$. These ROS produce toxic products such as malondialdehyde (MDA) from lipids byoxidizing cell membrane lipids. Another mechanism that causes tissue damage is the activation of cyclogenase-2 enzyme (COX-2) due to the increased intracellular calcium during ischemia and the release of proinflammatory prostaglandins and ROSs from arachidonic acid ${ }^{4}$.

This information summaries the pathogenesis of gastric I/R injury and the importance of antioxidant and antiinflammatory drugs for treatment. This study examined the protective effectiveness of dexmedetomidine, which is an alpha-2 adrenergic receptor agonist, in I/R damage of the stomach. Dexmedetomidine inhibits sympathetic activity by presynaptic activation of alpha- 2 adrenoreceptors in the central nerve system and causes decreased blood pressure and heart rate, sedation, and anxiolysis. In addition, it provides analgesia via alpha- 2 adrenoreceptors in the spinal cord 8 .

Dexmedetomidine is also known to protect stomach tissue from indomethacin damage, due to its antioxidant activity 9 . It has been reported that dexmedetomidine inhibits the induction of COX-2 and other proinflammatory cytokines ${ }^{10}$. These information indicate that dexmedetomidine may protect the stomach from oxidative and inflammatory damage associated withl/R. The aim of this study is to investigate the effect of dexmedetomidine on $\mathrm{I} /$ Rinduced gastric injury in rats, biochemically and histopathologically.

\section{Methods}

A total of 18 male albino Wistar rats weighing 260-280 $\mathrm{g}$ were used in the experiment. They were obtained from Atatürk University Medical Experimental Practice and Research Center. The animals were housed in groups at normal room temperature $\left(22^{\circ} \mathrm{C}\right)$ under suitable conditions and fed before the experiment. Animal experiments were performed in accordance with the National Guidelines for the Use and Care of Laboratory Animals and were approved by the local animal ethics committee of Atatürk University, Erzurum, Turkey (Ethics Committee Number: 16 Dated: 26.12.2019).

\section{Chemicals}

Sodium thiopental (IE-Ulagay, Istanbul) and dexmedetomidine (Abbott Co., UK.) were used for this evalution.

\section{Experimental groups}

Before the experiment, 18 animals were divided into three equal groups. Each group included six male albino Wistar rats. The groups were named asgastric ischemia reperfusion group (GIR), gastric ischemia reperfusion group (DGIR)that was induced and $50 \mu \mathrm{g} / \mathrm{kg}$ dexmedetomidine was administered, and healthy group(HG).

\section{Experiment procedure}

In order to carry out this experiment, $50 \mu \mathrm{g} / \mathrm{kg}$ dexmedetomidine was administered intraperitoneally (i.p.) to the DGIR animal group. Distilled water was administered as solvent to the GIR and HG groups with the same volume and method. Thirty minutes after the administration of dexmedetomidine and distilled water, $25 \mathrm{mg} / \mathrm{kg}$ of thiopental sodium was injected into all rat groups (i.p.) and anesthesia was achieved by making the rats breath xylazine at appropriate intervals. After the thiopental sodium injection, the rats were kept waiting for an appropriate period for surgery. The appropriate period for surgical intervention is considered when the animals remain immobile in the supine position ${ }^{11}$. Then, a laparotomy with a $2.5 \mathrm{~cm}$ midline incision was applied to the rats, under sterile conditions. In order to induce ischemia reperfusion lesions, the celiac artery was clamped with clips to create ischemia for 1 hin the DGIR and GIR groups. The abdominal region of the HG group was opened without applying clips to the celiac artery and was closed by suturing. After $1 \mathrm{~h}$, the clip was removed and reperfusion was achieved for $3 h^{12}$. At the end of the third hour of reperfusion, all animals were sacrificed with high dose 
(50 mg/kg) thiopenteal anesthesia. Then, biochemical and histopathological examinations were performed on the stomach tissue removed from the animals.

\section{The biochemical analysis}

\section{Determination of MDA}

Determination of MDA is based on measuring the absorbance of the pink colored complex formed by thiobarbituric acid (TBA) and MDA at high temperature $\left(95^{\circ} \mathrm{C}\right)$, spectrophotometrically at a wavelength of $532 \mathrm{~nm}^{13}$. Homogenates were centrifuged at $5000 \mathrm{~g}$ for $20 \mathrm{~min}$, and these supernatants were used to quantify MDA. Then, $250 \mu \mathrm{L}$ homogenate, $100 \mu \mathrm{L} 8 \%$ sodium dodecyl sulfate (SDS), $750 \mu \mathrm{L} 20 \%$ acetic acid, $750 \mu \mathrm{L}$ $0.08 \%$ TBA, and $150 \mu \mathrm{L}$ distilled water were pipetted into capped test tubes and vortexed. After the mixture was incubated at $100{ }^{\circ} \mathrm{C}$ for $60 \mathrm{~min}, 2.5 \mathrm{~mL}$ of $\mathrm{n}$-butanol was added on it and spectrophotometrically measured. The amount of red color formed was determined by using 3-mL cuvettes at $532 \mathrm{~nm}$, and the MDA amount of the samples was determined by using the standard graphic created using the MDA stock solution prepared before, by considering the dilution coefficients.

\section{The determination of myeloperoksidaze (MPO) activity}

The MPO activity was measured according to the modified method of Bradley et al. ${ }^{14}$. The homogenized samples were frozen and centrifuged at $1500 \mathrm{~g}$ for $10 \mathrm{~min}$ at $4{ }^{\circ} \mathrm{C}$. The MPO activity in the supernatants were determined by adding $100 \mathrm{~mL}$ of the supernatant to $1.9 \mathrm{~mL}$ of $10 \mathrm{mmol} / \mathrm{L}$ phosphate buffer ( $\mathrm{pH}$ equal to 6.0 ) and $1 \mathrm{~mL}$ of $1.5 \mathrm{mmol} / \mathrm{L}$ o-dianisidine hydrochloride containing $0.0005 \%$ (wt/vol) hydrogen peroxide. The changes in absorbance at $450 \mathrm{~nm}$ of each sample were recorded on anultraviolet-visible (UV-Vis)spectrophotometer.

\section{The determination of tGSH}

5,5'-dithiobis (2-nitrobenzoic acid) (DTNB) in the measurement medium is a disulfide chromogen and is easily reduced by sulfhydryl group compounds. The resulting yellow color was spectrophotometrically measured at $412 \mathrm{~nm}^{15}$. Homogenates were centrifuged at $12000 \mathrm{~g}$ for 10 minand supernatants were used to determine the amount of GSH. Then, $1500 \mu \mathrm{L}$ of measurement buffer (200 mmol/L Tris- $\mathrm{HCl}$ containing $0.2 \mathrm{mmol} / \mathrm{L} \mathrm{EDTA}$, $\mathrm{pH}=8.2), 500 \mu \mathrm{Lof}$ supernatant, $100 \mu \mathrm{Lof}$ DTNB, and $7900 \mu \mathrm{L}$ of methanol were vortexed by pipetting in capped test tubes. The mixture was left to incubate for $30 \mathrm{~min}$ at $37^{\circ} \mathrm{C}$ and, then, measurements were made by spectrophotometer. The amount of yellow color formed was read by using 3-mL quartz cuvettes at $412 \mathrm{~nm}$, and the GSH amount of the samples was determined by using the standard graphic created using the GSH stock solution prepared before, by considering the dilution coefficients.

\section{The superoxide dismutase (SOD) analysis}

Measurements were performed according to the method of Sun et al. ${ }^{16}$. When xanthine is converted into uric acid by xanthine oxidase, SOD forms. If nitroblue tetrazolium (NBT) is added to this reaction, SOD reacts with NBT and a purple-colored formazan dye occurs. The sample was weighed and homogenized in $2 \mathrm{~mL}$ of $20 \mathrm{mmol} / \mathrm{L}$ phosphate buffer containing $10 \mathrm{mmol} / \mathrm{L}$ EDTA at $\mathrm{pH}$ 7.8. The sample was centrifuged at $6000 \mathrm{rpm}$ for $10 \mathrm{~min}$ and, then, the brilliant supernatant was used as assay sample. The measurement mixture containing $2450 \mu \mathrm{L}$ measurement mixture $(0.3 \mathrm{mmol} / \mathrm{L}$ xanthine, $0.6 \mathrm{mmol} / \mathrm{L}$ EDTA, $150 \mu \mathrm{mol} / \mathrm{L}$ $\mathrm{NBT}, 0.4 \mathrm{~mol} / \mathrm{L} \mathrm{Na}_{2} \mathrm{CO}_{3}, 1 \mathrm{~g} / \mathrm{L}$ bovine serum albumin), $500 \mu \mathrm{L}$ supernatant and $50 \mu \mathrm{L}$ xanthine oxidase (167 Unit/Liter) was vortexed. Then it was incubated for $10 \mathrm{~min}$. At the end of the reaction, formazan was formed. The absorbance of the purple-colored formazan was measured at $560 \mathrm{~nm}$. As the quantity of the enzyme increases, the quantity of oxygen radicals reacting with NMT decreases.

\section{The histopathological examination}

All tissue samples were first identified in a $10 \%$ formaldehyde solution for light microscope assessment. Following the identification process, tissue samples were washed under tap water in cassettes for $24 \mathrm{~h}$. Samples were then treated with conventional grade of alcohol (70, 80,90 and $100 \%$ ) to remove the water within tissues. Tissues were then passed through xylol and embedded in paraffin. Four-to-five micron sections were cut from the paraffin blocks and hematoxylin-eosin staining was administered. Their pictures were taken following the Olympus DP2-SAL firmware program (Olympus Inc. Tokyo, Japan) assessment. For semiquantitative analysis of histopathological examinations were evaluated as mucosal degeneration, dilatation, congestion, polymorphonuclear cell infiltration, mucosal edema and scored between 0 to 3. The histopathological assessment was carried out by the histologist blind for the study groups.

\section{The statistical analysis}

Statistical analyses were conducted by using IBM SPSS Statistics for Windows, version 19 (Armonk, NY: IBM Corp.). Descriptive statistics were calculated for each variable.The 
results were presented as mean \pm standard deviation (SD) for continuous variables. The significance of the variations between the groups was determined by using the one-way variance analysis (ANOVA) method, followed by the analysis by Tukey's test. A value of $p<0.05$ was considered statistically significant. While comparing groups for histopathological grades KruskalWallis test was used and Dunn's test was applied as post hoc.

\section{Results}

\section{The biochemical results}

The values of all study groups are shown comparatively in Table 1. The detailed analysis of each parameters is explained below.

Malondialdehyde levels were found to be significantly higher in the GIR ischemia reperfusion group (9.94 \pm 0.06 $\mu \mathrm{mol} / \mathrm{g}$ ) compared to the $\mathrm{HG}$ group (5.16 $\pm 0.29 \mu \mathrm{mol} / \mathrm{g})$. A statistically significant decrease was observed in the DGIR group compared to the GIR group ( $p<0.05)$. There was no significant difference between the DGIR and HG groups in terms of MDA levels.

Myeloperoxidaselevels were found to be significantly higher in the GIR group $(9.13 \pm 0.06 \mu \mathrm{mol} / \mathrm{g})$ compared to the HG group $(4.32 \pm 0.07 \mu \mathrm{mol} / \mathrm{g})$. The decrease in MPO levels was statistically significant in the DGIR group compared to the GIR group ( $p<0.05$ ) (Fig.1).

Total glutathione levels were found to be $7.65 \pm$ $0.07 \mathrm{nmol} / \mathrm{g}$ in the HG group, while it was found to be 3.25 $\pm 0.11 \mathrm{nmol} / \mathrm{g}$ in the GIR group; this difference was statistically significant $(p<0.05)$. In the DGIR group, tGSH levels were found to be $6.61 \pm 0.08 \mathrm{nmol} / \mathrm{g}$ and it was statistically significant compared to both GIR and HG groups $(p<0.05)$.

When the SOD levels were compared, a statistically significant decrease was observed in the GIR group (8.26 \pm $0.27 \mathrm{U} / \mathrm{g}$ ) compared to the HG group $(19.5 \pm 0.76 \mathrm{U} / \mathrm{g})$ $(p<0.05)$. Superoxide dismutase levels were found to be significantly higher in the DGIR group $(17.2 \pm 0.95 \mathrm{U} / \mathrm{g})$ compared to the GIR group $(p<0.05)$. There was no significant difference between the HG and DGIR groups in terms of SOD levels $(p=0.097)$ (Fig. 2).

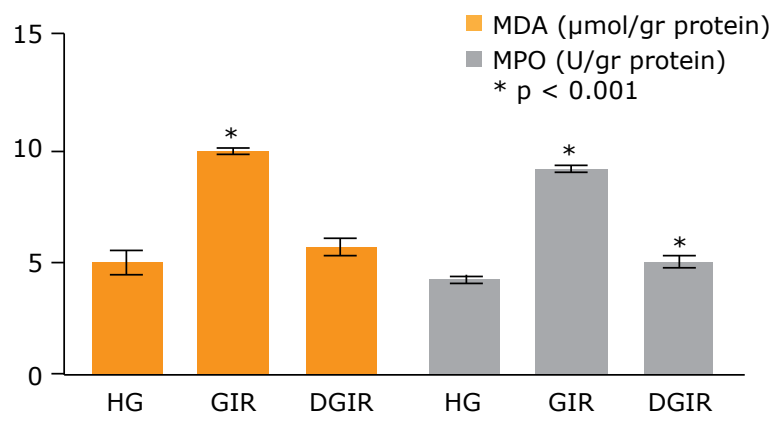

MDA: malondialdehyde; MPO: myeloperoxidase;GIR: gastric ischemia reperfusion group; DGIR: gastric ischemia reperfusion+ dexmedetomidine $50 \mu \mathrm{g} / \mathrm{kg}$ group; $\mathrm{HG}$ : healthy group. $\mathrm{N}=6$.

Figure 1-The amounts of MDA and MPO levels on stomach tissue at experimental groups. Bars are mean \pm SD. The healthy group is compared with GIR and DGIR groups.

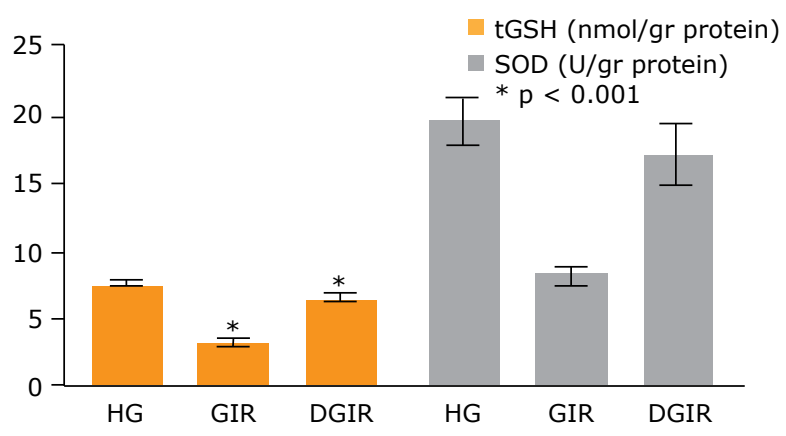

SOD:superoxide dismutase; tGSH: total glutathione; GIR: gastric ischemia reperfusion group; DGIR: gastric ischemia reperfusion+ dexmedetomidine $50 \mu \mathrm{g} / \mathrm{kg}$ group; $\mathrm{HG}$ : healthy group. $\mathrm{N}=6$.

Figure 2 - The amounts of tGSH and SOD levels on stomach tissue at experimental groups. Bars are mean \pm SD. The healthy group is compared with GIR and DGIR groups.

Table 1 - Biochemical results of the study groups.

\begin{tabular}{|c|c|c|c|c|c|c|}
\hline & \multicolumn{2}{|c|}{ HG $(n=6)$} & \multicolumn{2}{|c|}{ GIR $(n=6)$} & \multicolumn{2}{|c|}{ DGIR $(n=6)$} \\
\hline & Mean \pm SD & $\begin{array}{c}\text { Median } \\
(\text { Min-Max })\end{array}$ & Mean \pm SD & $\begin{array}{c}\text { Median } \\
(\text { Min-Max })\end{array}$ & Mean \pm SD & $\begin{array}{c}\text { Median } \\
(\text { Min-Max })\end{array}$ \\
\hline $\begin{array}{c}\text { MDA } \\
(\mu \mathrm{mol} / \mathrm{g} \text { protein })\end{array}$ & $5.19 \pm 0.29$ & $\begin{array}{c}5.15 \\
(4.13-5.99)\end{array}$ & $9.94 \pm 0.06 *$ & $\begin{array}{c}9.96 \\
(9.70-10.18)\end{array}$ & $5.73 \pm 0.17^{* *}$ & $\begin{array}{c}5.87 \\
(4.88-5.99)\end{array}$ \\
\hline $\begin{array}{c}\text { MPO } \\
\text { (U/g protein) }\end{array}$ & $4.32 \pm 0.07$ & $\begin{array}{c}4.28 \\
(4.12-4.65)\end{array}$ & $9.13 \pm 0.06 *$ & $\begin{array}{c}9.13 \\
(8.86-9.34)\end{array}$ & $5.10 \pm 0.09 * *,+$ & $\begin{array}{c}5.16 \\
(4.68-5.32)\end{array}$ \\
\hline $\begin{array}{c}\mathrm{tGSH} \\
(\mathrm{nmol} / \mathrm{g} \text { protein) }\end{array}$ & $7.65 \pm 0.07$ & $\begin{array}{c}7.69 \\
(7.41-7.84)\end{array}$ & $3.25 \pm 0.11^{*}$ & $\begin{array}{c}3.14 \\
(3.11-3.85)\end{array}$ & $6.61 \pm 0.08^{* *},+$ & $\begin{array}{c}6.71 \\
(6.26-6.82)\end{array}$ \\
\hline $\begin{array}{c}\text { SOD } \\
\text { (U/g protein) }\end{array}$ & $19.50 \pm 0.76$ & $\begin{array}{c}19.50 \\
(17.0-22.0)\end{array}$ & $8.26 \pm 0.27^{*}$ & $\begin{array}{c}8.60 \\
(7.10-8.80)\end{array}$ & $17.21 \pm 0.95^{* *}$ & $\begin{array}{c}18.20 \\
(13.7-19.2)\end{array}$ \\
\hline
\end{tabular}

* $p<0.001$ compared to HG. ${ }^{* *} p<0.001$ compared to GIR. $+p<0.001$ compared to HG. HG: Healthy group GIR: Gastric ischemia reperfusion group; DGIR: Gastric ischemia reperfusion + dexmedetomidine $50 \mu \mathrm{g} / \mathrm{kg}$ group. 


\section{The histopathological findings}

The scores of histopathological assessments are shown at Table 2.The healthy control (HG) group showed normal histological architecture of the gastric tissue, surface epithelium, glands of the tunica mucosa, and the gastric stratification (Fig. 3). In the examination of the GIR group, it was observed that the surface epithelium was torn off in places, the gland recesses were reduced, the neck areas of the glands were opened, the base regions were edematous, and the blood capillaries were intenselydilatated and congested (Fig. 4). In addition, in the samples belonging to this group, polymorphonuclear cell infiltration was noted in the connective tissue area adjacent to the vascular and gland bases (Fig. 5). When the samples belonging to the DGIR group were evaluated, it was found that epithelium, gland and vascular structures were close to normal histological formation, regeneration developed in the epithelium, edema regressed in the gastric glands, The polymorphonuclear leukoycte (PMNL) cells substantially reduced. Blood vessels were generally normal also some blood vessels were mildly dilatated (Fig. 6).

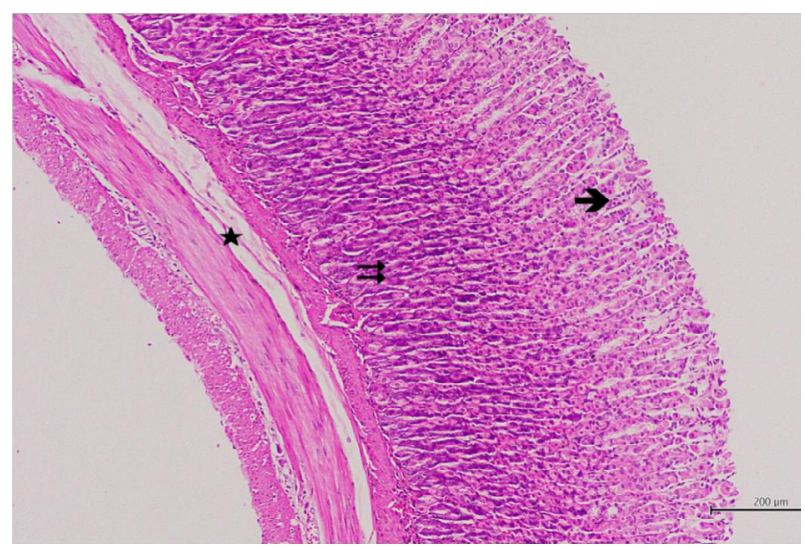

Figure 3- Hematoxylin-eosin staining in gastric tissue in healthy control group; $\rightarrow$ : epithelium, $\rightrightarrows$ : gastric glands, $\star$ : blood vessels, $100 \times$.

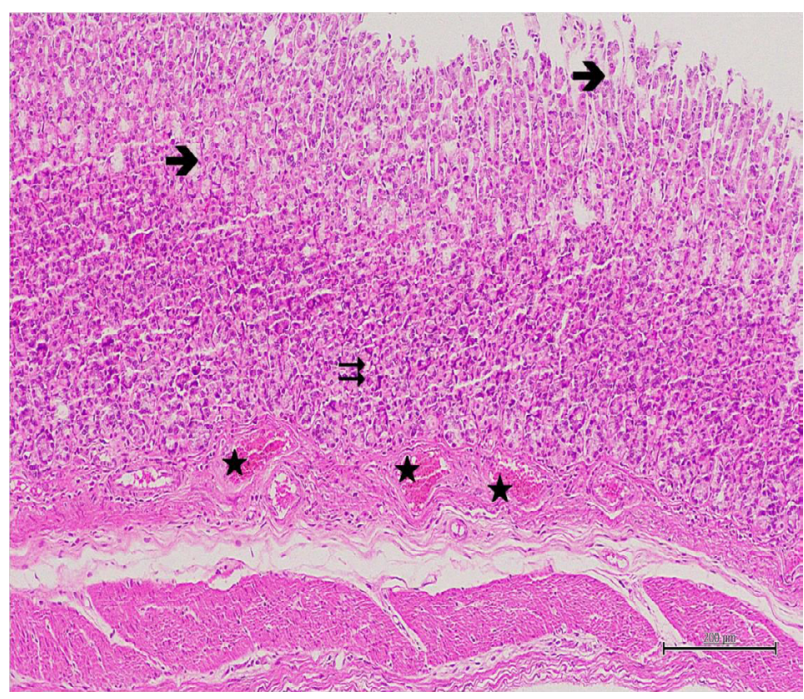

Figure 4 - Hematoxylin-eosin staining in gastric tissue in GIR group; $\rightarrow$ : degenerated and shed epithelium, $\rightrightarrows$ : edematous gastric glands, $\star$ : congested and dilatated blood vessels, $100 \times$.

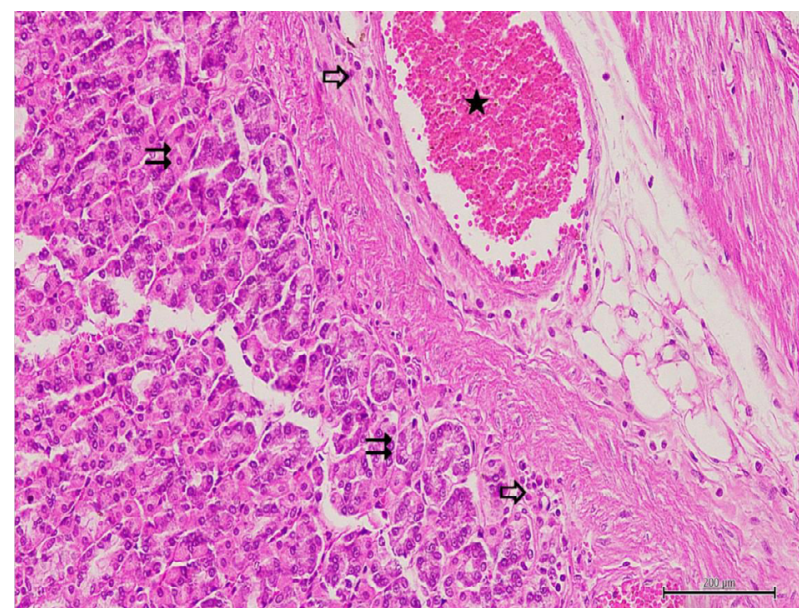

Figure 5 - Hematoxylin-eosin staining in gastric tissue in GIR group; $\rightrightarrows$ : edematous gastric glands, $\Rightarrow$ : polymorphonuclear cell infiltration, $\star$ : congested and dilatated blood vessels, 200x.

Table 2 - Histopathological examination of the gastric tissues in study groups.

\begin{tabular}{|c|c|c|c|c|}
\hline \multirow{3}{*}{ Mucosal degeneration } & \multicolumn{3}{|c|}{ Groups } & \multirow{2}{*}{$\mathbf{p}$} \\
\hline & HG & GIR & DGIR & \\
\hline & $0.0 \pm 0.0$ & $2.56 \pm 0.31 a$ & $0.50 \pm 0.11$ & $<0.001$ \\
\hline Dilatation & $0.0 \pm 0.0$ & $2.58 \pm 0.29 a$ & $0.22 \pm 0.25 b$ & 0.001 \\
\hline Congestion & $0.0 \pm 0.0$ & $2.72 \pm 0.14 a$ & $0.33 \pm 0.10$ & $<0.001$ \\
\hline Polymorphonuclear cell infiltration & $0.0 \pm 0.0$ & $2.53 \pm 0.29 a$ & $0.19 \pm 0.19 b$ & 0.001 \\
\hline Mucosal edema & $0.0 \pm 0.0$ & $2.64 \pm 0.16 a$ & $1.11 \pm 0.52$ & $<0.001$ \\
\hline
\end{tabular}

Results were presented as mean \pm SD. Kruskal-Wallis test was performed when comparing groups. For pairwise comparisons Dunn's test was used. aStatistically significant $(p<0.05)$ when compared with HG, bwhen compared with GIR. 


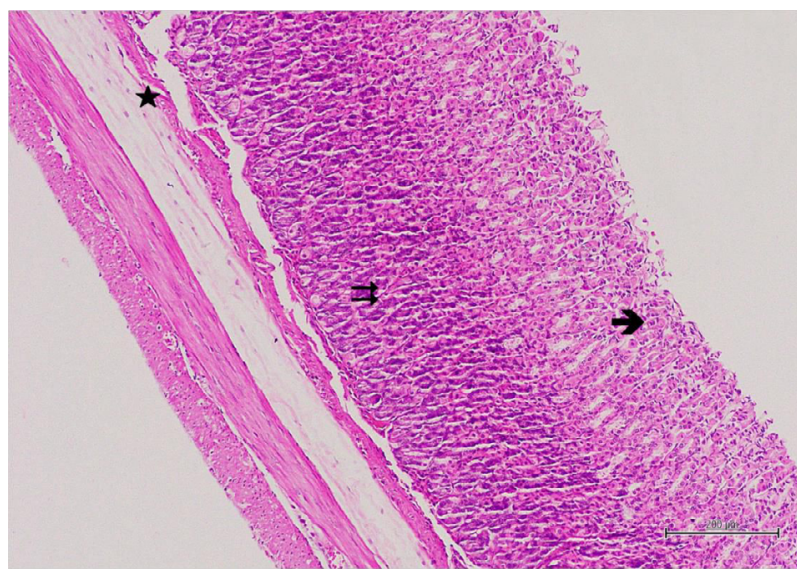

Figure 6 - Hematoxylin-eosin staining in gastric tissue in DGIR group; $\rightarrow$ : epithelium, $\rightrightarrows$ : gastric glands, $\star$ : mild dilatated blood vessels, $100 \times$.

\section{- Discussion}

Alpha-2adrenergic receptor ( $\alpha 2-A R)$ agonists have been used successfully in many clinical settings, considering various actions including sedation, analgesia, anxiolytic, perioperative sympatholytic, cardiovascular stabilizing effects, reduced anesthetic requirements, and preservation of respiratory function ${ }^{17}$. Anti-inflammatory and antioxidant activities have also been reported in the literature. Thanks to its wide spectrum of action and side effects limited to hemodynamic effects, dexmedetomidine have been used for many clinical applications as premedication, intraoperative use,locoregional anesthesia, procedural sedation,controlled hypotension etc ${ }^{17}$. There are many studies investigating the effectiveness of dexmedetomidine especially on the repairment of kidney, lung, liver and brain tissue damages ${ }^{18-22}$. However, in the literature, there are a limited number of studies on the protective effects of dexmedetomidine on stomach.

In the study of Chen et al. ${ }^{18}$, it was found that dexmedetomidine improved renal dysfunction, reduced oxidative stress, suppressed apoptosis, and decreased ROS formation by inhibiting noradrenaline release. Therefore, they experimentally demonstrated that dexmedetomidine was protective against stress-inducing acute kidney damage by suppressing apoptosis and reducing oxidative stress. In the study of Güzel et $a{ }^{1}{ }^{19}$, anti-inflammatory and antioxidant effect of dexmedetomidine has been shown to suppress the harmful effects of $\mathrm{HCL}$-related acute lung injury experimentally induced in the lung. Sha et al. ${ }^{20}$ demonstrated the effectiveness of dexmedetomidine in reversing liver functions by its antioxidant and antiapoptotic effects on oxidative stress.It was also shown to reduce inflammation and apoptosis in heart tissue via AMPK-GSK3
BETA and was recommended in surgical patients with heart diseases ${ }^{21}$. Huang et al. ${ }^{22}$ found that propofol and dexmedetomidine have different antineuroinflammatory and neuroprotective effects.

In a study conducted in an in vitro environment in 2016, it was observed that dexmedetomidine increased SOD levels and decreased MDA levels ${ }^{23}$.In this study, it was also observed that dexmedetomidine applied after experimentally induced ischemia-reperfusion in the stomach has an antioxidant effect. In addition, oxidant parameters MDA and MPO were found to be low, while the antioxidant parameters tGSH and SOD levels were high,in the dexmedetomidine group. Dexmedetomidinehas been reported to display its antiinflammatory effect by inhibiting the induction of COX-2 and other proinflammatory cytokines.

Dexmedetomidine is also known to protect stomach tissue from indomethacin damage due to its antioxidant activity. Polat et al. ${ }^{9}$ showed that dexmedetomidine increases antioxidant parameters and decreases oxidant enzymes, and suggested that the antiulcerative action mechanism of dexmedetomidine is due to this antioxidant activity. In this study, overproduction of reactive oxygen radicals induced by the reperfusion of the ischemic tissue was found to be lower in the DGIR group compared to the GIR group, and histopathological examination of the tissueswas similar to the HG group.

Ina study investigating the anti-inflammatory activity of dexmedetomidine on the liver and intestine, dark eosinophilic cytoplasm andhepatocytes with heterochromatic nuclei in liver sections were rare and a limited inflammation in the local area was present, in the dexmedetomidinegroup; and a significant decrease in histopathological damage scoring was observed ${ }^{24}$. It was reported that dexmedetomidine reduced oxidative stress in organs and corrected histopathological changes in liver. In this study, it was found that the epithelial, glandular, and vascular structures in the DGIR group after ischemia reperfusion were similar to the control group ${ }^{25}$. The dexmedetomidine corrected the damage caused by experimental ischemia-reperfusion in the stomach by regulating the oxidant-antioxidant balance was found at our study. This biochemical improvement was also confirmed by histopathological examination of the stomach tissue.

Current evidence suggests that disruption of the oxidative mechanism of cells and changes of ATP levels in tissue may be the basis of tissue damage ${ }^{25}$. The results of our research findings supported this view especially increased oxidative stress caused damage to the stomach tissue. Administration of dexmedetomidine turned the oxidative balance in favor of antioxidants and prevented tissue damage. 


\section{Conclusions}

It has been biochemically and histopathologically shown that ischemia-reperfusion process causes oxidative damage in gastric tissue. On the other hand, dexmedetomidine was found to prevent oxidative damage in the stomach by increasing the antioxidant effect. These results indicate that dexmedetomidine may be useful in the treatment of ischemia-reperfusion-related gastric damage.

\section{Authors' contribution}

Design the study: Kuyrukluyildiz $\mathrm{U}$ and Suleyman $\mathrm{H}$; Critical revision: Kuyrukluyildiz $U$ and Yazici GN; Technical procedures: Yazici GN , Gulaboglu M and Suleyman H; Acquisition of data: Kuyrukluyildiz $U$, Gulaboglu $M$ and Suleyman; Statistics analysis: Delen LA; Final approval: Kuyrukluyildiz U D, Onk D and Delen LA;

\section{Data availability statement:}

Data will be available upon request

\section{Funding}

Not applicable

\section{Acknowledgments}

Not applicable

\section{References}

1. Peña-Mercado E, Garcia-Lorenzana M, Beltran NE. Histomorphometric analysis with a proposed tissue lesion index in ischemia-reperfusion induced gastric mucosa damage. Histol Histopathol. 2018;33(10):1047-58. https://doi.org/10.14670/hh-11-999

2. Keshavarzi Z, Mohebbati R, Mohammadzadeh N, Alikhani. The protective role of estradiol \& progesterone in male rats, following gastric ischemia-reperfusion. Acta Endocrinol (Buchar). 2018;14(1):30-5. https://doi. org/10.4183/aeb.2018.30

3. Kisaoglu A, Borekci B, Yapca OE, Bilen H, Suleyman H. Tissue Damage and Oxidant/Antioxidant Balance. Eurasian J Med. 2013;45(1):47-9. https://doi.org/10.5152/eajm.2013.08

4. Yapca OE, Borekci B, Suleyman H. Ischemia-Reperfusion Damage. Eurasian J Med. 2013;45(2):126-7. https://doi. org/10.5152/eajm.2013.24

5. Semenza GL. Cellular and Molecular Dissection of Reperfusion İnjury: ROS Within and Without. Circ Res. 2000;86(2):117-8. https://doi.org/10.1161/01.RES.86.2.117
6. Parks DA, Granger DN, Physiology L. Ischemia-induced vascular changes: role of xanthine oxidase and hydroxyl radicals. Am J Physiol. 1983;245(2):G285-9. https://doi. org/10.1152/ajpgi.1983.245.2.G285

7. Del Maestro D. An approach to free radicals in medicine and biology. Acta Physiol Scand Suppl. 1980;492:153-68.

8. Aantaa R. Assessment of the sedative effects of dexmedetomidine, an alpha 2-adrenoceptor agonist, with analysis of saccadic eye movements. Pharmacol Toxicol. 1991;68(5):394-8. https://doi. org/10.1111/j.1600-0773.1991.tb01259.x

9. Polat B, Albayrak $Y$, Suleyman B, Dursun $H$, Odabasoglu F, Yigiter M, Halici Z,Suleyman H. Antiulcerative effect of dexmedetomidine on indomethacin-induced gastric ulcer in rats. Pharmacol Rep. 2011;63(2):518-26. https://doi. org/10.1016/S1734-1140(11)70518-7

10. Sun J, Zheng S, Yang N,Chen B, He G, Zhu T. Dexmedetomidine inhibits apoptosis and expression of COX-2 induced by lipopolysaccharide in primary human alveolar epithelial type 2 cells.Biochem Biophys Res Commun. 2019;517(1):89-95. https://doi.org/10.1016/j. bbrc.2019.07.023

11. Demiryilmaz I, Turan MI, Kisaoglu A, Gulapoglu M, Yilmaz I, Suleyman $H$. Protective effect of nimesulide against hepatic ischemia/reperfusion injury in rats: Effects on oxidant/antioxidants, DNA mutation and COX-1/COX-2 levels. Pharmacol Rep. 2014;66(4):647-52. https://doi. org/10.1016/j.pharep.2014.02.015

12. Wada K, Kamisaki Y, Kitano M, Kishimoto Y, Nakamoto K, Itoh T. A new gastric ulcer model induced by ischemiareperfusion in the rat: Role of leukocytes on ulceration in rat stomach. Life Sci. 1996;59(19):PL295-301. https://doi. org/10.1016/0024-3205(96)00500-0

13. Ohkawa H, Ohishi N, Yagi K. Assay for lipid peroxides in animal tissues by thiobarbituric acid reaction. Anal Biochem. 1979;95(2):351-8. https://doi. org/10.1016/0003-2697(79)90738-3

14. Bradley PP, Priebat DA, Christensen RD, Rothstein G.Measurement of Cutaneous Inflammation: Estimation of Neutrophil Content with an Enzyme Marker. J Invest Dermatol. 1982;78(3):206-9. https://doi.org/10.1111/15231747.ep12506462

15. Sedlak J, Lindsay RH. Estimation of total, protein-bound, and nonprotein sulfhydryl groups in tissue with Ellman's reagent. Anal Biochem. 1968;25(1):192-205. https://doi. org/10.1016/0003-2697(68)90092-4

16. Sun Y, Oberley LW, Li Y. A simple method for clinical assay of superoxide dismutase. Clin Chem. 1988;34(3):497-500. https://doi.org/10.1093/clinchem/34.3.497

17. Kaur M, Singh PM. Current role of dexmedetomidine in clinical anesthesia and intensive care. Anesth Essays Res. 2011;5(2):128-33. https://doi.org/10.4103/02591162.94750 
18. Chen $\mathrm{Y}$, Feng $\mathrm{X}, \mathrm{Hu} \mathrm{X}$, Sha J, Li $\mathrm{B}$, Zhang $\mathrm{H}$, Fan $\mathrm{H}$. Dexmedetomidine Ameliorates Acute Stress-Induced Kidney Injury by Attenuating Oxidative Stress and Apoptosis through Inhibition of the ROS/JNK Signaling Pathway. Oxid Med Cell Longev. 2018;2018:4035310. https://doi.org/10.1155/2018/4035310

19. Güzel A, Doğan E, Türkçü $G$, Kuyumcu M, Kaplan I, Çelik F, Yıldırım ZB. Dexmedetomidine and Magnesium Sulfate: A Good Combination Treatment for Acute Lung Injury?J Invest Surg. 2019;32(4):331-42. https://doi.org/10.1080 /08941939.2017.1422575

20. Sha J, Zhang $H$, Zhao $Y$, Feng $X$, Hu X, Wang C, Song $M$, Fan $H$. Dexmedetomidine attenuates lipopolysaccharideinduced liver oxidative stress and cell apoptosis in rats by increasing GSK-3 $3 / \mathrm{MKP}-1 / \mathrm{Nrf2}$ pathway activity via the $\alpha 2$ adrenergic receptor. Toxicol Appl Pharmacol. 2019;364:144-52. https://doi.org/10.1016/j. taap.2018.12.017

21. He Y, Yang Z, Li J, Li E. Dexmedetomidine reduces the inflammation and apoptosis of doxorubicin-induced myocardial cells. Exp Mol Pathol. 2020;113:104371. https://doi.org/10.1016/j.yexmp.2020.104371
22. Huang C, Ng OT-W, Chu JM-T, Irwin MG,Hu X, Zhu S, Chang RC-C, Wong GT-C. Differential effects of propofol and dexmedetomidine on neuroinflammation induced by systemic endotoxin lipopolysaccharides in adult mice. Neurosci Lett. 2019;707:134309. https://doi. org/10.1016/j.neulet.2019.134309

23. Zhang W-D, Zhang H, Wang H, Zhang N, Du CY, Yu J, Feng Z-G. Protective effect of dexmedetomidine against glutamateinduced cytotoxicity in PC12 cells and its mechanism. Nan Fang Yi Ke Da Xue Xue Bao. 2017;37(2):150-6. https://doi. org/10.3969/j.issn.1673-4254.2017.02.02

24. Gul M, Kayhan B, Elbe H, Dogan Z, Otlu A. Histological and Biochemical Effects of Dexmedetomidine on Liver during an Inflammatory Bowel Disease. Ultrastruct Pathol. 2015;39(1):6-12. https://doi.org/10.3109/01913123.201 3.829150

25. Tüfek A, Tokgöz O, Aliosmanoglu I, Alabalik U, Evliyaoglu $O$, Çiftçi T, Güzel A,Yıldırım ZB. The protective effects of dexmedetomidine on the liver and remote organs against hepatic ischemia reperfusion injury in rats. Int J Surg. 2013;11(1):96-100. https://doi.org/10.1016/j. ijsu.2012.12.003 